\title{
PH.D.-AFHANDLING OM "SYNCRETISM: THE PROBLEM OF DEFINING A CATEGORY"
}

Ved et offentligt forsvar for afhandlingen, Syncretism: The Problem of Defining a Category, indleveret til bedømmelse ved Det Teologiske Fakultet, Aarhus Universitet, erhvervede Anita Maria Leopold ph.d.-graden samme sted den 29. oktober 2004. Bedømmelsesudvalget bestod af formand, lektor Peter Steensgaard Paludan, Aarhus Universitet, professor Luther H. Martin, Department of Religion, The University of Vermont, USA, og professor Ingvild Scelid Gilhus, Seksjon for Religionsvitenskap, Universitetet i Bergen. Nedenfor bringes en redigeret udgave af Anita Maria Leopolds indledning og resume ved forsvaret fulgt af en redigeret udgave af Ingvild Scelid Gilhus' indleg ved samme lejlighed.

\section{Indledning og resumé ved Anita Maria Leopold}

Da jeg for snart mange år siden fattede interesse for synkretisme $\mathrm{i}$ forbindelse med studiet af hellenistisk religion, var jeg ikke fuldt ud klar over, hvilket kontroversielt emne jeg havde valgt. Det skulle vise sig at være overordentlig svært at få et ph.d.stipendium på basis af et studium i synkretisme. Men man plejer jo at sige, at der ikke er noget, der er så skidt, at det ikke også er godt for noget. Det passer i mit tilfælde. I stedet for at opgive emnet, da ventetiden på et stipendium trak ud, fortsatte jeg med at tale og skrive om synkretisme dels ved konferencer og dels til internationale tidsskrifter. På den måde fik jeg chancen for at blive redaktør på antologien Syncretism in religion. A Reader (Leopold \& Sinding Jensen 2004). Arbejdet med antologien har først og fremmest bidraget til Ph.d.-afhandlingens opprioritering af definitionsproblematikken i forskningshistorisk regi. Omvendt kom mit arbejde med Ph.d.-afhandlingen til at præge antologiens form, idet mine introduktioner til hvert kapitel samt konklusionen samlet danner 'en bog i bogen', hvori jeg foruden en kritisk analyse af antologiens artikler præsenterer min egen teori om synkretisme. Det har medvirket til Ph.d.-afhandlingens lidt usædvanlige form. Afhandlingen er (på nær en artikel) en samling af allerede udgivne arbejder: Syncretism in Religion. A Reader (2004), "Syncretism and the interaction of modes of religiosity: a formative perspective in 'Gnostic-Christian' movements in late antiquity" (2004). "The Architecture of Syncretism: A Methodological Illustration of the Dynamics of Syncretism" (2001), "Syncretism at the Cognitive Level". 1

\footnotetext{
${ }^{1}$ Artiklen "Syncretism at the cognitive level" vil blive udgivet i den forkortede udgave "Narrativity in view of a Theory of Syncretism" i forbindelse med en udgivelse af bidrag fra konferencen Religious Narrative, Cognition and Culture arrangeret ved Det Teologiske Fakultet, Aarhus Universitet.
} 
Afhandlingen er foruden et forord inddelt i fem kapitler: ${ }^{2}$

Part One (1-21): består af et resumé af afhandlingens undersøgelse.

Part Two: består af mine introduktioner samt konklusion fra antologien Syncretism in religion. Underkapitlerne i Part two følger derfor antologiens kapitelinddeling: Preface (1-5), Part I (1-17): “General Introduction", Part II (1-25): “The Historical Background of Syncretism: The Problem of Definition", Part III (1-16): "Syncretism: the Dynamics of Religion", Part IV (1-28): "Religions in Contact: Power, Syncretism, and Creolization", Part V (1-12): “Category Problems and Theoretical Suspense", Part VI (1-10): "Current Approaches to Syncretism in the Study of Religion”, Part VII (1-18): "Conclusion", Appendix (1-9).

Part Three (1-24): udgør artiklen "Syncretism and the Interaction of Modes of Religiosity: A Formative Perspective on "Gnostic-Christian" Movements in Late Antiquity", (2004).

Part Four (401-423): udgør artiklen "The Architecture of Syncretism: A Methodological Illustration of the Dynamics of Syncretism", (2001).

Part Five (1-56): udgør artiklen "Syncretism at the Cognitive level", (se note 1).

På trods af afhandlingens noget utraditionelle form følger den samme logiske form som en monografi. Part One forbinder forskningsresultaterne fra de forskellige undersøgelser til et hele. Part Two udgør tre vigtige tilgange: forskningshistorie, behandling af definitionsproblematikken og præsentation af afhandlingens teoretiske model. Derpå følger tre artikler, som hver især behandler et af de tre teoretiske niveauer $\mathrm{i}$ afhandlingens teoretiske model: Synkretisme på det sociale niveau, Synkretisme på det semiotiske niveau og Synkretisme på det kognitive niveau.

\section{Forskningshistoriske problemstillinger}

Forskningshistorien udgør en stor del af afhandlingens arbejde, idet begrebet synkretisme i nyere tid har været udsat for en betydelig kritik inden for både religionsvidenskaben og antropologien. Indledningsvis, inden jeg går videre med at præsentere disse forskningshistoriske vanskeligheder med hensyn til at definere synkretisme, skal der gives en kortfattet beskrivelse. Synkretisme refererer til det, at religiøse såvel som kulturelle enheder blandes på tværs af religiøse traditioner og ud over kulturelle grænser. Disse nye religiøse såvel som kulturelle 'blandingsformer' udgør til tider et nybrud inden for religion og kultur. Men begrebet synkretisme er siden reformationen blevet brugt som en nedsættende term til at beskrive 'urene' og 'afvigende' religiøse former. Begrebet er således blevet brugt til at sætte værdiskel mellem religioner og kulturer inden for både kristendommen og den tidlige antropologi. Derfor diskuterer man inden for forskningshistorien begrebets brugbarhed som en neutral, videnskabelig kategori. Det er blevet kritiseret for i værste fald at være bærer af værdinormer for og

\footnotetext{
${ }^{2}$ Sidenummereringen er ikke fortløbende, dels fordi afhandlingen består af en samling af udgivne arbejder, og dels fordi antologien endnu ikke var blevet udgivet, da jeg afleverede min ph.d.-afhandling. Den udkom først d. 30. oktober 2004, dagen efter mit forsvar.
} 
imod visse religiøse måder, og i bedste fald for at være en upræcis term, der blot henviser til et alment historisk fænomen, som at alle religioner er opstået som blandingsformer (se afhandlingens Part Two: Part II, 1-25). Forskningshistorisk set har man været delt i to lejre: de, der ønsker begrebet afskaffet, og de, der fortsat ønsker at beholde det med henblik på en ny og forbedret definition. Afhandlingen repræsenter et forsvar for et fortsat brug af begrebet, men med en teoretisk funderet redefinering af det. Mit forsvar for at beholde synkretisme som en religionsvidenskabelig kategori bygger overvejende på en erkendelse af, at videnskabelige begreber og kategorier ikke udelukkende er deskriptive, idet forskerens brug af et begreb rummer en fortolkning. Med fokus på de forskelligartede definitioner i den forskningshistoriske debat tager afhandlingen afsæt $\mathrm{i}$ en afklaring af fortolkningsforholdet mellem begreb og fænomen. For eksempel kan man i en ende af forskningshistorien beskrive synkretisme som noget positivt, fordi forskeren bor i et samfund, der tilskynder religiøs som kulturel amalgamation. I et andet samfund signalerer begrebet magt og undertrykkelse, og derfor er forskningsmiljøet her præget af en modstand i mod brugen af termen. Men er det så det samme fænomen, der tales om? Reelt set eksisterer der ikke et 'ét-til-ét' forhold mellem begreb og fænomen, idet definitionen farves af forskerens teoretiske optik. De objekter, som vi vælger at studere, er aldrig kun noget i sig selv, men de defineres i forhold til en bestemt videnskabelig tradition og dets brug af de herskende, teoretiske klassifikationer. Problemstillingen i forhold til synkretisme er præget af, at humanistisk forskning siden romantikken har rummet et paradoks mellem "det givne og det foranderlige" (Hastrup 1999, 100-01), og en gængs opfattelse af religion og kultur som 'rene' og ublandede enheder. Blandede kultur- og religionsformer er stadig en taksonomisk udfordring, fordi de oftest perspektiveres som modsætning til det 'givne' og traditionsbundne (Part Two: Part I). Synkretistiske processer opstår ofte i kølvandet af krig, imperialisme og etnisk forfølgelse, men også gennem almenmenneskelig kreativitet, kulturel pluralisme, religionsfrihed og nybrud. Hvad enten der er tale om møder mellem fremmede folk eller fremmede ideer, så er modstanden i visse religioner imod 'religionsblanderi' et udtryk for angsten for opløsning af det traditionsbundne. Diskussionen omkring synkretisme rummer altid sin modsætning 'anti-synkretisme', som ikke er blevet mindre aktuel i dag, hvor grænserne mellem kultur og religion enten omdefineres eller opløses. I de multietniske samfund i dag ser vi i stigende grad, hvordan forskellige traditioners religiøse symboler bliver 'mødesteder' for politiske såvel som religiøse formål. Derfor er det ikke utvetydigt, hvordan vi klassificerer 'hybride' former for religion og kultur. Det er kun igennem en ændret teoretisk optik, at vi kan løskøbe synkretisme fra de tidligere så problematiske definitioner.

\section{Synkretisme: mellem begreb og fænomen}

Afhandlingens forskningshistoriske gennemgang (Part Two) tjener til at rydde op i de mange uoverensstemmende definitioner af synkretisme. Jeg har valgt at lave en analytisk skillelinje mellem begreb og fænomen, fordi de fleste forskere, som beskæftiger sig med definitionsproblematikken, ikke har gjort meget for at præcisere, hvornår de taler 
om det ene eller det andet. Kort sagt sigter afhandlingen på en afklaring af begrebets forskellige brug anskuet i forhold til en præcisering af fænomenets eller fænomenernes karakter. Der synes at herske tvivl om, hvorvidt det er det samme fænomen, man taler om, når man sammenligner de meget forskelligartede definitioner. Professor Luther $\mathrm{H}$. Martin bad mig under forsvaret uddybe min deling af begreb og fænomen, idet han hævdede, at begreb og fænomen i princippet bør være det samme. Her kan jeg blot tilføje, at videnskabelige definitioner handler ikke om at opdage "det i naturen givne, men om at foreslå en teoretisk sammenhæng" (Hastrup 1999, 226). Det forholder sig nemlig med relationen mellem begreb og fænomen på samme måde, som det forholder sig med relationen mellem tegn og betydning. Forholdet må anskues hermeneutisk, idet 'das Ding an sich' skabes igennem sine fortolkninger. Da de mange fortolkninger af synkretisme indeholder flere og til tider modstridende teoretiske tilgange, er der blevet skabt et polyfont forhold mellem begreb og fænomen. For at få styr på de mange 'stemmer', der blandes i debatten, kræver det, at man specificerer definitionsproblematikken, så den bliver en undersøgelse af diskurser, der groft sagt kan deles i to grupperinger: de, der fokuserer på begrebets brugbarhed, og de, der mere er interesseret $\mathrm{i}$ fænomenets 'natur'. Derved bliver nogle af de mere markante, definitoriske modsætninger anskueliggjort. Med hensyn til begrebets brugbarhed diskuteres dets negative brug inden for teologien. Eller dets brug som hegemonisk begreb, der refererer til et bestemt problematisk menneskesyn, som det er tilfældet med kolonitidens nedvurderinger af andre folkeslag og deres religioner. Med hensyn til en afklaring af synkretismen som fænomen søger man at forstå den mere eller mindre universelle og dynamiske drivkraft bagved religiøs foranderlighed.

Differentieringen af begreb og fænomen indgår i afhandlingens diskursanalytiske synsvinkel. Som et resultat af de forskningshistoriske overvejelser fremgår det, at forskellige diskurser mødes og blandes i definitionen af synkretisme. Primært afdækkes herved de bagvedliggende motiver, der øver indflydelse på begrebets politiske og betydningsmæssige ståsted inden for religionsforskningen. Sekundært bistås dette af en undersøgelse af, hvordan blandingsfænomener opstår. Forstået sådan anskues fænomenet synkretisme ud fra nogle almene menneskelige grundvilkår så som indlæring og transmission af viden. Herunder henvises til bl.a. sprog- og kognitionsteorier om de biologiske og psykologiske forudsætninger for menneskets evne til at blande forskelligartede elementer sammen og omforme dem til helstøbte betydningssystemer. Til sidst overvejer jeg de taksonomiske problemer, som vi er stillet overfor med hensyn til at fremstille den bedst mulige deskriptive analyse af empiriske eksempler. Hvis kategorien synkretisme skal have en heuristisk funktion, har vi også brug for en velfunderet deskriptiv analyse, som kan identificere forskellige former for 'synkretismer', uden at vi derved bringer fortidens fordomme om synkretisme med os (Part Two: Part V, VII). Derfor må vi undersøge samspillet mellem synkretisme og forskellige religiøse modi, der kan spille en afgørende rolle i forhold til, hvor 'åben' eller 'lukket' en tradition agerer over for påvirkninger udefra. I afhandlingen lægges der derfor vægt på, at vi forholder taksonomien til en teoretisk velovervejet analyse (Part One, s. 8, Part Three, 
Part Five). Den tredelte analyse model, som er kernen i afhandlingens redefinering af synkretisme, er således udviklet på baggrund af det forskningshistoriske materiales teoretiske og historiske mangfoldighed. I kraft af dette definitoriske oprydningsarbejde må definitionen af synkretisme forholdes til hvert enkelt niveau. Synkretisme på det sociale niveau defineres $i$ forhold til en afgrænsning af sociale spilleregler og magtstrukturer. Synkretisme på det semiotiske niveau afgrænses i forhold lingvistiske dybdestrukturer for transformation af betydning. Synkretisme på det kognitive niveau defineres her som et kognitivt fænomen, som en slags 'hybrid bevidsthed'. Modellen afspejler den overordnede definition af synkretisme ved at se på de tre niveauers samspil.

\section{Den tredelte analysemodel}

Indlæring er en proces, hvori ny viden reformuleres i sammenhæng med individets foreliggende viden. Religiøse eller kulturelle blandingsformer dannes kognitivt set ganske naturligt igennem vor opvækst, idet vi instinktivt indsætter ny viden i et fortolkningsforhold til den foreliggende, indlærte viden. Men ny viden kan repræsentere et psykologisk problem, hvis den udfordrer gammel viden og dermed skaber et modsætningsforhold til den gammelkendte forestillingsverden. Nybrud kan bogstavelig talt være et brud med en veletableret identitet. Det er en kendt sag, at læring er knyttet sammen med tilhørsforhold. Vores vilje til læring og viden står ikke kun i forhold til individets lyst og evne, men også i forhold til sociale og kulturelle forventninger. For at præcisere kompleksiteten mellem det kognitive mulige og det socialt problematiske ved synkretisme har jeg udarbejdet en analytisk model, der undersøger synkretisme på tre niveauer: det sociale, det semiotiske og det kognitive. Hvert niveau udgør en problemstilling, som først skal belyses særskilt, før man kan udrede de facetterede aspekter, der antages i fortolkningsforholdet mellem fænomen og begreb.

Undersøgelsen af synkretisme på det sociale niveau fokuserer på mødet mellem konkurrerende religiøse grupper, der deler de samme religiøse kilder, men som fortolker dem meget forskelligt (Part Three). Ud fra en sammenlignende analyse af kirkefaderen Irenæus af Lyons skrifter og kristen-gnostiske skrifter foreslår jeg, idet jeg støtter mig til antropologen Harvey Whitehouse's teori om divergerende religiøse modi, at en divergerende religiøsitet har spillet en afgørende rolle på uenigheden mellem dem. Traditionelt set er gnosticismen i modsætning til kristendommen blevet klassificeret som typisk synkretistisk. Jeg hævder derimod, at også Irenæus' skrifter afslører samtidens synkretistiske tendenser. Forskellen i fortolkning beror på forskellen mellem religiøse modi. Medens de 'gnostiske' tekster afspejler en mystisk og mere imagistisk religiøsitet, udgør Irenæus' tekster en dogmatisk religiøsitet. ${ }^{3}$ I den forbindelse afslører analysen

\footnotetext{
${ }^{3}$ Ingvild Gilhus fremsatte i den forbindelse en kritik af mit syn på 'gnostikerne' for ikke at være tilstrækkelig tidssvarende. I dag anser man begrebet 'gnosticisme' for at være misvisende, fordi de overordnet set var kristne, selvom de praktiserede en anden form for kristendom end kirkefædrene. Jeg godtager kritikken, men det ændrer ikke ved min stipulering af, at årsagen til konflikten ligger i meget forskellige måder at rekodificere det fælles narrative.
} 
også, at de divergerende modi spiller ind på rekodificeringen af det fælles narrative. Under kapitlet om synkretisme på det semiotiske niveau (Part IV) vurderes mønsteret for den betydningsmæssige transformation, som er foranlediget af en synkretistisk proces. ${ }^{4}$ Ferdinand de Saussures deling mellem to sproglige niveauer langue og parole benyttes som forbillede for den teoretiske opbygning af min analyse. Jeg antager hermed, at stort set de samme fortolkningsmæssige regler gør sig gældende med hensyn til sprog og religion, idet de begge indbefatter semiotiske betydningssystemer. Fortolkning er generelt set ikke vilkårlig. Ethvert nyt begreb (sprogligt eller billedligt) må kunne indordnes under nogle givne forestillinger eller spilleregler for at kunne afkodes af sine brugere. Således ligger der under enhver synkretistisk dannelse et bestemt forestillingsparadigme (langue), som indsætter ethvert nyt element (parole) i en særlig fortolkningsramme. På den måde sker der en transformation i betydning af det indførte element. Men det indførte element udgør ligeledes en ny fortolkningsmæssig refleksion, som kan ændre de traditionelle forestillinger. Gennem en slags 'spejleffekt' af nye og gamle tegn udvikles det nye forestillingsparadigme. Ud fra en semiotisk synsvinkel er fænomenet synkretisme ikke blot lig med 'lån' eller 'eklekticisme'. I så fald er det motiverede lån, der fremkalder en forandring i betydning i konteksten. Ifølge min forståelse af synkretismens arkitektur opstår der en nyskabelse ud af samspillet mellem fortolkningsparadigme og det indførte element.

Den sidste del af afhandlingens undersøgelse er analysen af synkretisme på det kognitive niveau (Part Five). Jeg hævder herunder, at synkretisme er en kreativ dynamik i religion, der peger på nogle grundvilkår, hvad angår kognition og kommunikation. Jeg inddrager forskellige teorier om kognition, narrativitet og kultur. ${ }^{5}$ Undersøgelsen af de tre religiøse områder Hopi profeti, Neo-Hasidisk reinkarnationslcere og Den synkretistiske strid i Lutheran Church of Missouri Synod, bekræfter, at der er et samspil mellem det kognitive og det sociale niveau. I alle tre eksempler ser man en tendens til, at den tværreligiøse kommunikation skaber nye sociale behov, der fremprovokerer, at visse symboler gøres til 'mødesteder' for mere tidssvarende fortolkninger. Narrativitet tjener som et medie for kreativitet i kultur og religionsmøder, fordi fortællinger kan forme såvel som reformere vore erfaringer om os selv og andre. Dog udtrykte man en vis skepsis overfor min brug af Gilles Fauconnier og Mark Turners teori om "conceptual blending", fordi det hævdedes, at den passede for godt på min beskrivelse af synkretismens struktur. Kort fortalt karakteriserer 'conceptual blending' menneskets formodede kognitive evne til at 'fusionere' meget forskelligartede, mentale kategorier, som derved danner nye former, begreber, erkendelse m.m. Vi er prædisponerede, hævdedes det, til at skabe forestillingsmæssige 'blandinger' (conceptual blendings) - uden denne mentale kreative evne ville vi slet ikke være i stand til at skabe noget nyt. Især var Luther Martin

\footnotetext{
${ }^{4}$ Igen er det udvalgte tekstmateriale kirkefaderen Irenæus af Lyons Bevis for den Apostolske Prcediken og den valentinske tekst Sandhedens Evangelium.

${ }^{5}$ Her skal følgende nævnes: Rukmini Bhaya Nair vedrørende narrativitet, Louis Cozolino om neurovidenskab og psykoterapi, Gilles Fauconnier og Mark Turner om kognition, Terrence Deacon om symbolteori og kognition, samt Daniel J. Siegel om neurobiologi.
} 
skeptisk over for Fauconnier og Turners påstand om 'conceptual blending' som en kognitiv prædisposition. Han anså dem for blot at have fremlagt en almen narrativ struktur frem for en kognitiv. Selvom jeg er delvis enig i hans kritik, udtrykte Martin i for høj grad en biologisk reduktionisme. Han fokuserer på de mest primitive trin i den menneskelige evolution som primær forklaring på det moderne menneskes kognition. Men fordi vi stadig bærer 'firbenshjernens' aftryk i vores moderne hjerner, udelukker det ikke udbyttet ved at studere senere trin på udviklingsskalaen. Den nyere kognitionsforskning har vist, at narrativitet i allerhøjeste grad er et emne for studiet af kognition, fordi vi rent faktisk kan bevise, at fortællinger kan fremprovokere eller ændre specifikke erfaringer og emotioner. Undersøgelsen af synkretisme på det kognitive niveau påpeger de ændringer, som synkretistiske religiøse fortællinger formår at skabe i forskellige individers eller gruppers syn på sig selv. Dynamikken i synkretistiske processer kan være, at de ændrer noget ved menneskers selvforståelse, som virker emotionelt stimulerende. Således bekræfter Rabbi Gershoms og hans klienter gensidigt deres formodede erfaringer fra tidligere liv som jøder under Holocaust. Det samme forhold gør sig gældende for euro-amerikanske individer, som tror, at de er Hopi indianernes længe ventede 'Hvide bror'.

'Empati' og 'analogisk kodning' er særdeles vigtige faktorer for de nævnte eksempler. Kort sagt virker det, som om det at se sig selv i den anden også er begrundet med en følelse af empati for den anden. Omvendt glemmer man tilsyneladende også at se bort fra fundamentale forskelle mellem sig selv og den anden.

\section{Konklusion}

Ph.d.-afhandlingens vigtigste opgave har først og fremmest været at få ryddet op i de mange diskurser og definitioner, som gør kategorien videnskabelig uklar. Dernæst foreslår jeg nogle nye teoretiske sammenhænge, som 'overskrider' tidligere fordomme om begrebet, idet jeg mener, at et begreb bør rumme en videnskabelig praksis, som flytter sig i forhold til dets materiale. Sagt på en anden måde bør vi bruge vore videnskabelige kategorier til at søge nye erkendelser, selv når et begreb indeholder levn fra et menneskesyn eller en videnskabelig praksis, som vi har forladt. Kun gennem vedblivende studier af emnet finder vi en ny teoretisk optik, som kan komme en række af problemstillinger til gode selv ud over det specifikke problemfelt. Som sagt lever levn ikke videre af sig selv, og vi behøver ikke forlade et studieområde på grund af gamle fordomme. I så fald bliver der ikke meget tilbage af den humanistiske forskning. Med hensyn til fænomenet synkretisme er det jo en kendsgerning, at der sker en sammensmeltning af betydningsrum, som flytter sig ud over snævre kulturelle og religiøse grænser. For mig at se er synkretisme et godt synonym for interkulturel kreativitet. Afhandlingens tre analytiske niveauer belyser på hver deres måder, hvorledes det er et fremherskende fænomen i tværreligiøs kommunikation. Dette forsvarer også kategoriens videnskabelige placering inden for religionsvidenskaben samt andre videnskabelige studier af tværkulturelle fænomener. 


\section{Litteratur}

HASTRUP, KIRSTEN

1999 Viljen til Viden. En Humanistisk grundbog, Gyldendal, København.

2001 "The Architecture of Syncretism: A Methodological Illustration of the Dynamics of Syncretism", Historical Reflexions/Reflexions Historiques, Vol. 27, no. 3, 401-23.

LEOPOLD, ANITA MARIA

2004 "Syncretism and the interaction of modes of religiosity: a formative perspective in 'Gnostic-Christian' movements in late antiquity”, in: Harvey Whitehouse and Luther H. Martin, eds., Theorizing Religions Past. Archaeology, History, and Cognition, AltaMira Press: Walnut Creek, Lanham, New York, Toronto, Oxford, 105-24.

LEOPOLD, ANita MARIA \& JEPPE Sinding JensEN

2004 Syncretism in Religion. A Reader, Equinox Publishing Ltd., London.

\section{Indlæg ved Ingvild Sælid Gilhus}

Anita Maria Leopold forsvarte 29. oktober 2004 sin Ph.d.-avhandling om synkretisme ved Aarhus Universitet. Avhandlingen har et usedvanlig format. Den består av to deler, hvorav den ene er en antologi redigert av Anita M. Leopold og Jeppe Sinding Jensen med innledninger skrevet av Leopold, den andre omfatter tre artikler forfattet av Anita Leopold. Men selv om denne avhandlingen har en usedvanlig form, utgjør den allikevel en helhet. Temaet er selve kategorien synkretisme. Tilnærmingen er teoretisk. I antologien viser Leopold sin oversikt over synkretismebegrepets forskningshistorie og foretar en kritisk gjennomgang av den, mens hun i artiklene anvender synkretismebegrepet som et analytisk redskap i utforskningen av religionshistorisk kildemateriale.

\section{Antologien}

Antologien, Syncretism in the Study of Religion. A Reader, inneholder nitten artikler om synkretisme. De spenner fra Geradus van der Leeuw til en rekke nålevende forfattere, noen av dem publisert for første gang på engelsk (blant annet Ulrich Berner og Kurt Rudolph). Leopold har skrevet hovedinnledningen, innledninger til antologiens fem deler og en konklusjon. Omtrent samtidig med at disputasen ble avholdt ble antologien publisert (Anita M. Leopold og Jeppe Sinding Jensen, eds., Syncretism in Religion: A Reader, Equinox Publishing/Routledge, London 2004/2005).

I innledningene i antologien presenterer Anita Leopold på klar måte de ideer og perspektiver som blir diskutert i dens forskjellige artikler. Hun viser sitt overblikk over synkretismetemaet og relaterer artiklene til hverandre. Slik får hun frem "the state of the art" for synkretismebegrepet, samtidig som hun bringer inn kritiske perspektiver og antyder nye tilnærminger.

I konklusjonen presenterer så Leopold sin egen modell for studiet av synkretisme. Modellen har tre nivåer og omfatter det samfunnsmessige, det semiotiske og det kognitive. Det kognitive nivået er, ifølge Leopold, det mest grunnleggende, også for de 
to andre nivåene. På denne måten sikter Leopold på å fange kompleksiteten i kategorien og nyansere den slik at den blir et nyttig analytisk instrument.

\section{Artiklene}

I tillegg til antologien var disputasgrunnlaget tre artikler, hvorav to var publisert eller i trykk da avhandlingen ble levert: "Syncretism and the interaction of modes of religiosity: a formative perspective in "Gnostic-Christian" movements in late antiquity", in: Luther H. Martin and Harvey Whitehouse, eds., Theorizing Religious Past: Archaeology, History, and Cognition, Altamira Press, Walnut Creek (i trykk) (ms, 23 s.); "The Architecture of Syncretism. A Methodological Illustration of the Dynamics of Syncretism”, Historical Reflections/Reflexion Historiques 27, 3, 2001, 401-23; "Syncretism at the Cognitive Level" (ms $55 \mathrm{~s}$.).

I disse artiklene tester Anita Leopold sitt synkretismebegrep ved å utforske dets praktiske anvendelse. Hun har særlig benyttet eksempler fra senantikk religionshistorie og vestlig nyreligiøsitet, religioner som gjerne har blitt karakterisert som synkretistiske. For de to første artiklenes vedkommende dreier det seg om forholdet mellom katolsk kristendom og gnostisisme, mens hun i den siste artikkelen tar eksemplene fra nåtiden.

I de to første artiklene kontrasterer hun katolsk kristendom, spesielt Irenaeus' skrifter, med gnostisisme, særlig Sannhetens evangelium, men også skrifter som Allogenes og Poimandres (som er hermetisk) trekkes inn. I analysen bringer hun inn Harvey Whitehouse' teorier og hans kontrast mellom en doktrinær og en imagistisk modus. Hun søker å vise at Irenaeus fokuserer på det doktrinære og belærende, mens Sannhetens evangelium er en billedrik tekst som inviterer til andre typer tilnærminger.

I den tredje artikkelen, "Religious Narrativity, Cognition and Culture", tester Leopold sine ideer om synkretisme på tre samtidsfenomen. Det dreier seg om hippiers bruk av hopi-indianernes religion, en rabbiner som tror på reinkarnasjon og Lutheran Church of Missoury Synod som utviste et av sine medlemmer fordi vedkommende deltok i et arrangement i etterkant av 11. september. Anklagen mot det utviste medlemmet gjaldt blant annet synkretisme. I denne artikkelen benytter Anita Leopold seg særlig av kognisjonsforskning. Poenget er å vise at historiefortelling er en grunnleggende menneskelig aktivitet som ikke minst foregår ved hjelp av "blending", det at betydninger fra ulike domener bringes sammen. Synkretisme blir på denne måten ikke et perifert fenomen, men er uttrykk for en grunnleggende måte som mentale representasjoner utvikles på i menneskelig kultur og samfunn.

\section{Diskusjon}

Anita Leopolds Ph.d.-avhandling har en rekke kvaliteter og er på mange måter forbilledelig i sitt opplegg. Forbilledligheten gjelder særlig hvordan Leopold foretar en systematisk og grundig analyse av et religionshistorisk begrep, viser vilje og evne til å utvikle begrepet teoretisk og gjør en innsats for å prøve det ut på ulike former for religionshistorisk materiale. I denne avhandlingen kombinerer Anita Leopold forsk- 
ningshistorisk kunnskap med teoretiske og analytiske tilnærminger på en ambisiøs og vellykket måte.

Når det gjelder selve termen synkretisme har den en lang og innfløkt historie som Anita Leopold redegjør godt for. Synkretismebegrepet har gjerne vært brukt i kristen sammenheng og da på en nedsettende måte om fenomener som ble betraktet som "urene". Idealet var at religiøse fenomen og deres opprinnelser skulle være rene og ikke blandete. Anita Leopolds synkretismeprosjekt medfører derfor også at et noe "tvilsomt" begrep blir rehabilitert.

Noen spørsmål er grunnleggende i denne avhandlingen. Et av dem gjelder selve synkretismebegrepet. Er ikke alle kulturelle og religiøse prosesser i sitt vesen synkretistiske og hvis så er tilfelle, er det da i det hele tatt meningsfylt å operere med en slik kategori? Leopold sier selv at religionshistorien "confirms that every religion is in "essence" syncretistic - there are nor pristine origin or essences" (s. $6 \mathrm{i}$ innledningen). Siden alle religiøse nydannelser ifølge dette egentlig er synkretistiske $\mathrm{i}$ betydningen at de ikke har noen essens, må Leopold argumentere for at synkretismebegrepet faktisk trengs.

Hun knytter også fenomenet synkretisme til et mønster som tilsvarer eller ligner den grunnleggende måten vi mennesker tenker på. Her forholder hun seg til en gren av kognisjonsforskningen, nemlig den som blant annet Mark Turner og Gilles Fauconnier representerer (The Way we Think, 2002), og til fenomenet "blending" (se overfor). Synkretismebegrepet kan i denne sammenheng betraktes som en underkategori av "blending". En måte Leopold imøtegår innvendingen på om at fenomenet synkretisme utvannes ved det at alle kulturelle fenomen egentlig er blandingsfenomen, er å avgrense synkretismebegrepet til bare å gjelde kryss-kulturelle fenomen.

I avhandlingen bruker Leopold en rekke teoretiske perspektiver, ikke minst fra kognisjonsforskningen der religionsforskningsmiljøet ved Aarhus Universitet har vært i forkant. Vi har allerede pekt på Turner og Fauconnier og begrepet "blending". Disse teoretikerne er imidlertid avvisende til den generative tilnærmingen som ellers er rådende i andre religionsfaglige kognisjonsmiljøer (USA, England, Finland). Dette forholdet hadde trengt ytterligere kommentarer i avhandlingen. Også Harvey Whitehouse og hans "modes of religiosity" blir trukket inn i Anita Leopolds analyser. Dette gjelder særlig i artiklene om kristendom og gnostisisme. Kombinasjonen av Turner/Fauconnier på den ene siden og Whitehouse på den andre kan imidlertid være noe problematisk, fordi disse forskerne bygger på forskjellige kognisjonsteorier som ikke umiddelbart er forenlige. Man kunne derfor ha ønsket seg en mer omfattende metateoretisk diskusjon der forholdet mellom de ulike kognisjonsteoretiske tilnæringene ble ytterligere klargjort.

Kritisk kan det videre bemerkes at Anita Leopolds konstruksjon av "gnostisisme" ikke er helt overbevisende. Denne konstruksjonen er gjort for mye i opposisjon til katolsk kristendom, og det er ikke tatt hensyn til at studiet av antikk kristendom har vært i rask endring i de senere år. Man anerkjenner idag en større kompleksitet enn man gjorde tidligere, og "gnostisisme" har i stigende grad blitt oppfattet som "a dubious category", for å bruke religionshistorikeren Michael Williams' ord (Rethinking 
“Gnosticism": an argument for dismantling a dubious category, Princeton University Press, Princeton, N.J., 1996). Leopold kjenner til Williams' arbeide og refererer til det flere ganger, men opprettholder allikevel et skille mellom gnostisisme og kristendom. Det kan man nok gjøre, men det er vanskelig å trekke skillet så skarpt og entydig som Leopold gjør. Når hun videre tar Sannhetens evangelium til inntekt for det som Williams karakteriserer som "a biblical demiurgical myth" kan det innvendes at dette skriftet $\mathrm{i}$ beste fall er en atypisk bibelsk demiurgisk myte, fordi det opererer med det kognitive begrepet 'villfarelse' som sitt skapende prinsipp, og ikke med en mytisk demiurg.

Det er også noe problematisk å knytte Harvey Whitehouse’ skille mellom imagistisk og doktrinær religion til antikk kristendom på den måten Leopold gjør. Forskjellene som Leopold påpeker mellom Sannhetens evangelium og Irenaeus' tekster, som Leopold tar som eksempler på henholdsvis imagistisk og doktrinær modus, kan heller være forskjeller mellom sjangre enn mellom kjetteri og ortodoksi. Såkalte imagistiske tekster er ikke begrenset til "gnostisisme", men kan like gjerne finnes i andre deler av kristendommen. Kort sagt kristendommen i de første århundrene var en mer kompleks størrelse enn det Leopold gir uttrykk for i denne fremstillingen.

Men selv om det kan etterlyses ytterligere metateoretiske diskusjoner, og selv om man kunne ha ønsket seg en større innsikt i kristendommens kompleksitet i antikken, må ikke avhandlingens åpenbare kvaliteter komme i skyggen av disse kritiske bemerkningene. Tvertimot må det fremheves at avhandlingen er en fruktbar kombinasjon av teoretiske perspektiver der narrativitetsteorier, symbolteorier og kognitive teorier har blitt satt til å arbeide sammen og faktisk gjør det. Særlig må Anita Leopolds lovende bruk av kognitive teorier påpekes, og spesielt de forbindelseslinjer hun har trukket mellom "blending" og synkretistiske dannelser der synkretistiske dannelser utgjør en type krysskulturelle "blendings". På samme måte ser også de skillene som Anita Leopold trekker opp mellom det samfunnsmessige, det semiotiske og det kognitive ut til å utgjøre finslepne instrumenter til fremtidige analyser av historiske prosesser.

Fortjenstfullt er videre det skillet Anita Leopold har påpekt mellom "synkretisme" som begrep og synkretisme som et fenomen. Det gjør at hun i sin gjennomgang av forskningshistorien klart skiller mellom forsøkene på begrepsdefinisjoner og klassifisering på den ene siden og forskning på fenomenet synkretisme, det vil si det som begrepet refererer til, på den andre. Det er en viktig distinksjon, som ofte har blitt oversett, og som fungerer som ytterligere et nyttig analyseinstrument i Anita Leopolds avhandling og til bruk for senere forskning. 